\title{
PENINGKATAN HASIL BELAJAR DAN KEGIGIHAN SISWA \\ PADA PELAJARAN KEWIRAUSAHAAN MELALUI \\ PEMBELAJARAN MODEL DISCOVERY INKUIRI \\ DAN PENUGASAN DI SMK MUH 2 METRO \\ TAHUN PELAJARAN 2012/2013
}

\author{
Sunaryo \\ Guru Kewirausahaan SMK Muhammadiyah 2 Metro \\ Su_naryo@yahoo.co.id
}

\begin{abstract}
ABSTRAK
Keberanian untuk meraih kesempatan dan menggunakan kesempatan untuk berkembang harus dikembangkan sejak di SMK. Untuk berwirausaha, seseorang harus memiliki sikap pantang menyerah dan ulet. Sikap tersebut merupakan kegigihan seorang wirausaha untuk mencapai kesuksesan. Memiliki sikap gigih merupakan salah satu keberhasilan mata pealajaran kewirausahaan di SMK, termasuk di SMK Muhammadiyah (Muh) 2 Metro. Selain hasil belajar kognitif, sikap gigih merupakan hasil belajar ranah afektif yang sangat penting dalam membangun mentalitas seorang wirausahawan. Tujuan penelitian ini untuk meningkatkan hasil belajar pada KD menunjukkan sikap pantang menyerah dan ulet siswa kelas IX TKR-1 dalam pembelajaran Kewirausahaan di SMK Muh 2 Metro, dan meningkatkan kegigihan siswa dalam wirausaha. Penelitian dilaksanakan diSMK Muh 2 Metro pada siswa kelas IX TKR-1 B, semester ganjil Tahun Pelajaran 2012/2013. Jumlah siswa 32 siswa. Metode yang digunakan adalah Penelitian Tindakan Kelas. Penelitian dilaksanakan selama tiga bulan dari bulan Juli sampai dengan bulan September tahun 2012. Peneliti dapat menyimpulkan bahwa hasil belajar, kegigihan belajar siswa dan proses pembelajaran Kewirausahaan, siswa kelas IX TKR-1 di SMK Muh 2 Metro pada KD menunjukkan sikap pantang menyerah dan ulet dapat meningkat melalui pembelajaran menggunakan pembelajaran discoveryinkuiri dan penugasan. Sehingga disarankan dalam penerapan Discovery Inkuiri musti diberikan tujuan yang jelas pada saat penugasan. Hal dimaksudkan agar siswa tidak cepat putus asa karena tujuan yang akan dicapai tersebut dapat dijadikan dasar untuk menentukan cara meraihnya. Berikan penugasan secara berkelompok dengan keluasan akses dan cara yang digunakan sehingga peran teman sebaya dapat dioptimalkan dalam menyelesaikan tugas yang diberikan. Metode pembelajaran discoveryinkuiri harus digunakan secara bertahap dengan melalui 11 anya jawab dan diskusi pada fase awal. Hal ini dilakukan untuk mendorong secara intensif intensitaskegigihan siswa.
\end{abstract}

Kata Kunci: Kewirausahaan, Discovery Inkuiri, Kegigihan, Hasil Belajar

\section{PENDAHULUAN}

Sebagai Sekolah Menengah Kejuruan (SMK) yang bertujuan untuk memberikan bekal keterampilan yang memadai, maka diharapkan para alumni SMK dapat segera mencari pekerjaan untuk mendapatkan penghasilan dan mencukupi kebutuhan. Namun demikian, seringkali peluang kerja yang diharapkan tidak tercapai atau bahkan tidak terbuka peluang pekerjaan yang sesuai dengan jurusan yang diambilnya. Di sinilah pentingnya pelajaran kewirausahaan di 
SMK. Siswa harus dapat melakukan wirausaha dengan melihat peluang yang ada. Mereka dapat mempertahankan kehidupan dan meraih kehidupan yang lebih baik.

Keberanian untuk meraih kesempatan dan menggunakan kesempatan tersebut untuk berkembang harus dikembangkan sejak di SMK. Untuk berwirausaha, seseorang harus memiliki sikap pantang menyerah dan ulet. Sikap tersebut merupakan kegigihan seorang wirausaha untuk mencapai kesuksesan. Memiliki sikap gigih merupakan salah satu keberhasilan mata pealajaran kewirausahaan di SMK, termasuk di SMK Muhammadiyah (Muh) 2 Metro.

Kegigihan belajar kewirausahaan rendah karena siswa melihat pelajaran tersebut hanya perlu menghafal dan tidak memberdayakan potensi. Penyelesaian tugas dengan cara memberikan kesem-patan kepada siswa untuk mengeksplorasi lingkungan sekitar dalam menemukan (discovery) dan mencari (inkuiri) peluang usaha yang dapat diraih merupakan pengalaman belajar yang sangat berharga. Kemudian untuk menggali dan memahami konteks dan materi bisa dilakukan tanya jawab, diskusi yang mendalam antarsiswa dalam kelas terkait dengan temuan dari proses discovery inkuiri. Kemudian untuk memperkuat hasil diskusi siswa dapat diberi penugasan dan hasil tugas tersebut menjadi bahan tanya jawab dan diskusi pertemuan berikutnya.

\section{KAJIAN PUSTAKA}

\section{Hasil Belajar}

Banyak definisi belajar yang telah dinyatakan oleh para ahlis. Belajar merupakan proses merubah perilaku, Gagne,(1992:66) memberikan dua definisi tentang belajar, yaitu: 1) belajar adalah suatu proses untuk memperoleh kegigihan pengetahuan, keterampillan, kebiasaan, dan tingkah laku; 2) belajar adalah pengetahuan atau keterampilan yang diperoleh dari instruksi. Dalam proses belajar terdapat dua fenomena yang berlaku yaitu: 1) keterampilan intelektual yang meningkat sejalan dengan meningkatnya umur dan latihan yang didapat individu; 2) belajar akan lebih cepat apabila strategi kognitif dapat dipakai dalam memecahkan masalah secara efisien.

Suatu proses pembelajaran dinyatakan berhasil ketika tujuan pembelajaran khusus dapat tercapai. Untuk mengetahui tecapai tidaknya tujuan pembelajaran khusus tersebut perlu diadakan tes. Setiap siswa yang mengikuti proses pembelajaran diharapkan dapat menguasai apa yang 
dipelajarinya. Pengukuran terhadap pencapaian belajar siswa tersebut dapat dilakukan dengan berbagai cara antara lain dengan memberikan tes lisan, atau tes tertulis, ulangan atau pujian pada waktuwaktu tertentu.

\section{Kegigihan dalam Kewirausahaan}

Hakikat pantang menyerah dan ulet adalah perjuangan yang tangguh penuh semangat, tidak putus asa, tidak mudah menyerah dan pantang berputus asa menghadapai kesulitan sampai kesulitan tersebut teratasi, Rajin, tekun dan ulet dalam berusaha dan melaksanakan tugasnya.Sikap pantang menyerah akan melahirkan pemenang.Di tengah perjalanan, seseorang pasti akan menemukan kendala dan hambatan. Orang yang kalah akan segera menyerah, dan seorang pemenang justru akan semakin maju. Pantang menyerah dan ulet merupakan perwujudan dari kegigihan.

Menjaga konsistensi kegigihan dan pantang menyerah sama artinya seperti kita pergi mencari rahasia sukses dari orang orang tersukses yang kita kagumi. Hal ini sebagaimana disampaikan bahwa,"Elang pernah jualan minyak goreng ke warungwarung atau donat ke sekolah-sekolah dasar di Bogor, namun sekarang sayapnya sudah membawanya terbang tinggi menjadi pengusaha properti”, (Kasali, 2010:1)
Konsistensi semangat juang harus selalu terpelihara dalam situasi dan kondisi apa pun, sebab hanya itu yang bisa membangkitkan diri dari setiap keterpurukan yang dialami selama perjalanan hidup, dalam mencari mimpi, cita - cita, dan harapan. Oleh karena itu kegigihan harus menjadi karakter wirausaha. Kegigihan akan membuat orang untuk terus berusaha dan berkarya agar mencapai impian.

\section{Pembelajaran Discovery Inkuiri}

Metode pembelajaran yang dapat melibatkan keaktifan siswa adalah metode penemuan (discovery) atau penyelidikan (inquiry).Inkuiri yang dalam bahasa Inggris "inquiry" mempunyai arti pertanyaan, pemeriksaan, atau penyeli-dikan.Salah satu metode discovery inkuiri adalah Inkuiri Terbimbing (Guided Inquiry). Hal ini sebagaimana disampai-kan bahwa "Metode Guided Inquiry berarti suatu kegiatan belajar yang melibatkan seluruh kemampuan siswa untuk mencari dan menyelidiki suatu permasalahan secara sistematis, logis, analitis, sehingga dengan bimbingan dari guru mereka dapat merumuskan sendiri penemuannya dengan penuh percaya diri", (Gulo, 2008:85).

Pembelajaran inkuiri dibentuk atas dasar discovery, sebab seorang siswa harus menggunakan kemampuannya dalam 
melakukan discovery dan kemampuan lainnya. Dalam inkuiri, seseorang bertindak sebagai seorang ilmuwan (scientist), melakukan ekperimen, dan mampu melakukan proses mental berinkuiri.... (Hamalik, 2007: 219).

\section{METODE PENELITIAN}

Penelitian dilakukan menggunakan metodePTK. Menurut Arikunto, et al (2006: 117) bahwa prosedur pelaksanaan penelitian tindakan kelas itu meliputi (1) planning, (2) acting, (3) observing, (4) reflecting. Langkahnya disebut dengan siklus, dan pelaksanaannya tidak hanya cukup satu kali, jika ternyata satu siklus belum menunjukkan adanya perubahan, maka dilakukan secara berulang sampai benar-benar tampak adanya perubahan sebagaimana yang diharapkan.

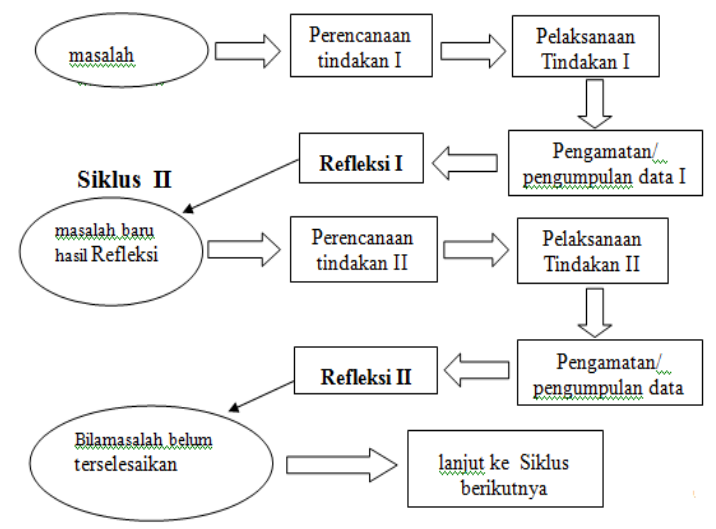

Gambar 1. Alur PTK

Pengamatan terhadap guru yang memberikan tindakan merupakan telaah untuk mempelajari langkah-langkah dalam menerapkan pembelajaran kontekstual. Untuk melakukan pengamatan terhadap fenomena tersebut dapat digunakan beberapa jenis instrumen atau catatan- yang bersifat naratif dan fokus terhadap kejadianspesifik. Dilakukan siklus berikutnya atau tidak didasarkan pada hasil refleksi dan indikator ketercapaian dari siklus sebelumnya. Perencanaan indikator harus jelas dan tegas, sehingga mudah mengidentifikasi ketercapaian tujuan.

Penelitian dilaksanakan diSMK Muh 2 Metro pada siswa kelas IX TKR-1 B, semester ganjil Tahun Pelajaran 2012/2013. Jumlah siswa 32 siswa, selama tiga bulan dari bulan Juli sampai September tahun 2012.

Indikator keberhasilan yang digunakan dalam PTK.

Tabel 2. Lama Tindakan dan Indikator Keberhasilan

\begin{tabular}{|c|c|c|c|}
\hline $\begin{array}{l}\text { Lama } \\
\text { Tindakan } \\
\text { (1 siklus) }\end{array}$ & Tujuan & Indikator Keberhasilan & Volume \\
\hline \multirow[t]{2}{*}{$\begin{array}{l}2 \times 2 \times 40 \\
\text { menit }\end{array}$} & $\begin{array}{l}\text { 1. Hasil belajar } \\
\text { Kewirausahaan }\end{array}$ & $\begin{array}{l}\text { Siswa mendapatkan skor } \\
70\end{array}$ & $75 \%$ \\
\hline & $\begin{array}{l}\text { 2. Kegigihan belajar } \\
\text { Kewirausahaan }\end{array}$ & $\begin{array}{l}\text { Siswa meningkatkan } \\
\text { Kegigihan pada } \\
\text { tingkatan tinggi }\end{array}$ & $60 \%$ \\
\hline
\end{tabular}

mendasarkan pada jenis metode yang akan diguna-kan, juga mempertimbangkan SKKD dan materi. Dalam hal ini SK-nya adalah "Menerapkan jiwa kepemimpinan”, KD-nya 
adalah "Menunjukkan sikap pantang menyerah dan ulet". Perencanaan tindakan pada siklus pertama dilakukan dua pertemuan.Pada pertemuan:

Pertama: 1) siswa membaca dan mendiskusikan serta mengerjakan tugas-tugas yang ada dalam Lembar Kerja Siswa (LKS); 2) Siswa dengan difasilitasi oleh guru mendiskusikan dan membahas LKS; 3) Siswa menyimak dan mencermati uraianjiwa kepemimpinan, pantang menyerah dan ulet; 4) Siswa dengan difasilitasi guru, mengerjakan dan mendiskusikan soal-soal yang diberikan; 5) Siswa menyimak penjelasan dan klarifikasi guru mengenai jiwa kepemimpinan, pantang menyerah dan ulet; 6) Siswa berperan secara aktif dalam kegiatan tanya jawab kelas yang difasilitasi oleh guru; 7) Siswa diberi tugas mencari naskah orang sukses bermula dari nol.

Pertemuan kedua, siswa mempresentasikan hasil tugas kelompok tentang jiwa kepemimpinan, pantang menyerah dan ulet.

Pelaksanaan tindakan menyesuaikan dengan perencanaan sebelumnya.Dalam hal ini menyesuaikan dengan jadwal pelajaran, SK-KD dan materi yang harus disampaikan sesuai dengan silabus. Guru menekankan siswa tentang pentingnya bertanya, mengomentari jawaban, merespon (menanggapi) pertanyaan atau kerugian, dan menstimulasi siswa aktif dalam Proses Belajar Mengajar (PBM). Dalam PBM guru harus mengupayakan terjadinya interaksi belajar mengajar secara multi arah dengan menggali pengalaman siswa dalam kehidupan sehari-hari, yang dilakukan untuk mendapatkan konteks (keterkaitan) ide dengan materi pelajaranjiwa kepemimpinan, pantang menyerah dan ulet.

Hasil pengamatan dari guru sejawat meliputi hasil pengamatan proses pembelajaran,kegigihan siswa dan hasil evaluasi setiap siklus. Hasil yang diperoleh tersebut selanjutnya dianalisis.Hasil analisis pengamatan dan evaluasi digunakan untuk mengetahui ada atau tidaknya peningkatan pada siklus berikutnya dan dibandingkan dengan kondisi sebelum perlakuan.

Instrumen penelitian yang digunakan adalah tes hasil belajar berbentuk esai. Daftar cek atau lembar pengamatan digunakan untuk menilai proses pembelajaran menggunakan metode discovery inkuiri dan penugasan. Angket digunakan untuk mengukur kegigihan siswa.Data bersifat kuantitatif yang telah diperoleh dianalisis menggunakan statistik deskriptif. Statistik deskriptif digunakan untuk menggambarkan ukuran pemusatan. Untuk mempermudah pemahaman data yang telah diolah tersebut ditampilkan dalam bentuk bagan atau grafik histogram.

\section{PEMBAHASAN HASIL PENELITIAN}

Hasil belajar yang diperoleh adalah sebagai berikut: 
Tabel 4.Statistik Deskriptif

\begin{tabular}{|r|l|r|r|r|r|r|}
\hline \multirow{2}{*}{ No } & \multirow{2}{*}{ Ukuran } & \multicolumn{4}{|c|}{ Siklus } & \multicolumn{2}{c|}{ Peningkatan } \\
\cline { 3 - 7 } & & Pra & \multicolumn{1}{c|}{ I } & \multicolumn{1}{c|}{ II } & Pra-I & I-II \\
\hline 1 & Rata-rata & 4.38 & 6.38 & 7.59 & 2.00 & 1.22 \\
\hline 2 & Standar Kesalahan & 0.11 & 0.16 & 0.23 & & \\
\hline 3 & Nilai Tengah & 4.00 & 7.00 & 8.00 & 3.00 & 1.00 \\
\hline 4 & Modus & 4.00 & 7.00 & 8.00 & 3.00 & 1.00 \\
\hline 5 & Simpangan Baku & 0.61 & 0.91 & 1.32 & & \\
\hline 6 & Variansi & 0.37 & 0.82 & 1.73 & & \\
\hline 7 & Kurtosis & -0.58 & 1.34 & 1.97 & & \\
\hline 8 & Kejulingan & -0.40 & -1.12 & -1.08 & & \\
\hline 9 & Rentang & 2.00 & 4.00 & 6.00 & & \\
\hline 10 & Nilai Terendah & 3.00 & 4.00 & 4.00 & & \\
\hline 11 & Nilai Tertinggi & 5.00 & 8.00 & 10.00 & & \\
\hline 12 & Jumlah & 140.00 & 204.00 & 243.00 & 64.00 & 39.00 \\
\hline 13 & BanyaknyaData & 32.00 & 32.00 & 32.00 & & \\
\hline
\end{tabular}

Peningkatan rata-rata terjadi sebesar 2,13 dari 4.4 pada prasiklus menjadi 6,53 pada Siklus I. Modus meningkat 2 dari 5 pada Prasiklus menjadi 7 pada Siklus I. Nilai tengah atau Median meningkat 3 dari 4 pada Prasiklus menjadi 7 pada Siklus I. Peningkatan hasil belajar dari Siklus I ke Siklus II. Peningkatan rata-rata terjadi sebesar 1,77 dari 6.07 pada Siklus I menjadi 7,83 pada Siklus II. Modus meningkat 2 dari 6 pada Siklus I menjadi 8 pada Siklus II. Nilai tengah atau Median meningkat 2 dari 6 pada Siklus I menjadi 8 pada Siklus II. Nilai terendah dari 5 menjadi 6 , nilai tertinggi dari 8 menjadi 10. Secara kumulatif jumlah meningkat 53 dari 182 pada Siklus I menjadi 235 pada Siklus II.Setiap aspek kegigihan, yaitu: 1) Penerimaan Terhadap Diri, 2) Memotivasi Diri, 3) Keoptimisan, 4) Perspektif Terhadap Fenomena, 5) Keberanian Mengambil Resiko, 6) Sikap Terhadap Tantangan, 7) Orientasi Proses, 8)
Konsistensi, 9, Keseimbangan Upaya dan Kreativitas, 10) Kemampuan Mengambil Pelajaran memberikan sebaran skor yang berbeda

Tabel 5. Sebaran Jawaban Angket Siklus II

\begin{tabular}{|c|c|c|c|c|c|c|c|c|c|c|c|c|c|c|c|c|c|c|c|}
\hline \multirow[t]{2}{*}{ Aspek } & \multicolumn{18}{|c|}{ Sebaran Jaw boban Angket } & \multirow[t]{2}{*}{ Jumlbh } \\
\hline & 1 & & 2 & & 3 & & 4 & 5 & & 6 & & 7 & & 8 & & 9 & & & \\
\hline Butir & 1 & & 3 & 45 & 6 & 7 & & $y$ & 10 & & 2 & & & & & & & 20 & \\
\hline Skor1 & 16 & 0 & 2 & 8 & 0 & 1 & & 3 & 1 & & & & & & & & & 0 & 47 \\
\hline Skor2 & 8 & & 0 & 312 & 2 & 15 & & 12 & 4 & 4 & 6 & & & & & 3 & 2 & 12 & 134 \\
\hline Skor3 & 7 & 7 & 2 & 46 & 26 & 8 & 12 & 5 & 15 & f & 9 & & 4 & & 1. & 11 & 18 & 3 & 174 \\
\hline Skor4 & 1 & & 8. & 171 & 4 & 8 & 14 & 16 & 12 & 8 & 4 & & 14 & & & & 10 & 17 & 189 \\
\hline $\mathrm{Im} \mid$ & 32 & & 3223 & & & & & & 32 & & 32 & & & & & & & & 544 \\
\hline
\end{tabular}

Jumlah skor 1 semakin menurun, hanya 51 kemudian jumlah skor 2 lebih besar dari jumlah skor 1. Hal ini menunjukan bahwa telah terjadi pergeseran Kegigihan dari rendah menjadi sedang.Selanjutnya jumlah skor 4 lebih besar dari jumlah skor 1, 2 dan 3, artinya kategori Kegigihan tinggi semakin banyak terdapat pada siswa-siswa.

Tabel 6.Sebaran Predikat Tingkat Kegigihan Prasiklus dan Siklus I

\begin{tabular}{|l|l|l|l|l|}
\hline \multirow{2}{*}{ No } & Predikat & \multicolumn{3}{|l|}{ Siklus } \\
\cline { 3 - 5 } & & Pra & I & II \\
\hline 1 & Tidak Gigih & 0 & 0 & 0 \\
\hline 2 & Kurang Gigih & 3 & 0 & 0 \\
\hline 3 & Cukup Gigih & 29 & 9 & 5 \\
\hline 4 & Kegigihan Tinggi & 0 & 23 & 27 \\
\hline & Jumlah & 32 & 32 & 32 \\
\hline
\end{tabular}

Berdasarkan tabel di atas maka dilihat terdapat peningkatan kegigihan belajar dari prasiklus ke siklus 1, dari siklus I ke siklus II.Peningkatan tersebut dapat dilihat predikat 
tidak gigih adalah 0 pada stiap siklus.Predikat kurang gigih pada Prasiklus 3 menjadi 0 pada Siklus I dan II.Predikat cukup gigih pada prasiklus 29 meningkat 9 pada Siklus I, kemudian turun menjadi 5 pada Siklus II.Predikat gigih tinggi pada Prasiklus 0 menjadi 23 pada siklus II dan 27 pada siklus II.

\section{PEMBAHASAN}

Perubahan perilaku merupakan hasil belajar yang diharapkan. Pengalaman merupakan guru yang terbaik. Penerapan discovery inkuiri merupakan sebuah proses pembelajaran yang memberikan pengalaman berharga bagi para siswa. Melalui pengalaman tersebut, para siswa mendorong dirinya untuk berani melakukan berbagai tindakan yang dianggap perlu untuk mencapai apa yang diinginkannya. Hal ini mendukung apa yang disampaikan bahwa, "Discovery terdapat pengalaman yang disebut 'Ahaa Experience' yang dapat diartikan 'Nah' ini dia. Inquiry learning tidak selalu sampai pada proses ini", (Supriyono, 2011:68). Pada saat yang sama, siswa tidak hanya berusaha dengan maksimal mencapai apa yang dicarinya, tetapi juga pemahaman terhadap -aturan selama proses pencapaian tersebut.
Peningkatan hasil belajar merupakan dampak dari interaksi materi yang dipelajari yang secara relevan ditemui pada saat proses discovery inkuiri. Paradigma pembelajaran jaman sekarang adalah 'harus' berpusat pada siswa (student centre oriented) yang akan tercermin dalam strategi discovery inkuiri. Jadi, discovery inkuiri lebih baik daripada ekspositori, dalam konteks materi dan waktu tertentu.

Hal ini sebagaimana pendapat, "Discovery learning menekankan pada pengalaman seperti yang dialami oleh peneliti ketika melakukan penemuan suatu temuan. Inquiry berarti guru harus menyediakan situasi sedemikian rupa sehingga siswa didorong untuk melakukan prosedur yang digunakan oleh penelitian.

Proses pembelajaran selalu berada dalam area waktu, karakteristik materi, ketersediaan alat/media, karakteristik siswa dan tingkat kesiapan siswa belajar. Untuk menjawab pertanyaan 'Besar' sebagaimana judul di atas, kita tidak bisa begitu saja menentukan pilihan.Harus diketahui dulu hal-hal yang terkait dengan pembelajaran. Pembelajaran discovery inkuiri layak diterapkan ketika, 1) kemandirian peserta didik cukup memadai, 2) Sumber referensi, media, alat dan bahan cukup, 3) Jumlah peserta didik dalam kelas relatif tidak 
banyak, 4) Materi pelajaran tidak terlalu dalam dan luas, 5) Waktu yang tersedia cukup.Dengan demikian, memilih strategi apa yang akan kita terapkan dalam pembelajaran menuntut kita untuk lebih dulu mengkaji berbagai aspek pendukungnya

Gagal dan jatuh merupakan proses yang sering dilalui setiap orang untuk mencapai tujuan yang ingin dicapai. Kegagalan memberikan banyak pelajaran bagi mereka yang mau mengambil makna. Bangkit dan mencoba lagi menjadi sebuah perjalanan hidup yang membangun kepercayaan diri sehingga orang akan terus berupaya memperbaiki dirinya untuk mendapatkan apa yang diharapkan. Gigih harus ditumbuh kembangkan untuk menghilangkan potensi keputusasaan dari setiap orang yang sedang berusaha.

Penugasan yang diberika untuk mensinergikan proses discovery dan inkuiri yang diterapkan terhadap siswa. Berbagai kesulitan yang dihadapi mendidik siswa untuk belajar bersikap, merubah stragtegi, mengadposi dan mengadaptasi berbagai teknik, dan bahkan merubah dirinya sendiri. Sebuah ungkapan "Keberhasilan seseorang bukan dinilai dari hasil yang telah dicapainya, tetapi dari berat ringan dan jumlah rintangan-rintangan yang ia hadapi saat berusaha meraih keberhasilan itu sendiri”, (Ginanjar, 2014:1).

Penugasan memberikan tujuan yang pasti yang dapat diraih oleh para siswa. Adanya tujuan tersebut, yaitu mengumpulkan berbagai naskah cerita tentang orang yang sukses dimulai dari usaha kecil dengan segala susah payahnya. Naskah tersebut selanjutnya dirangkum untuk dipresentasikan di depan kelas. Pesan moral yang diharapkan adalah sebuah tujuan yang jelas memberikan arah dan gerak upaya dari seseorang untuk dapat meraihnya, dan pada saat yang sama mengembangkan cara untuk meraihnya.

Siswa juga mengembangkan kemampuan kerjasama dengan pihak lain. Apakah kerjasama dengan teman sekolah, orang yang lebih dewasa, dan orang lain yang dianggap lebih pandai untuk membantu mengatasi kesulitan yang dihadapinya, untuk menyelesaikan tugas yang diberikan, seperti merangkumnya, dan siswa belajar untuk mempresentasikan. Siswa selanjutnya berusaha mengidentifikasi kelemahan yang ada pada dirinya kemudian berusaha untuk menguasainya. Misalnya, ketika mencari sumber belajar dan materi, bagaimana cara mengunduh, mengkopi, atau menyimpan halaman dari internet sesuai kebutuhan. 


\section{KESIMPULAN}

Peneliti dapat menyimpulkan bahwa hasil belajar, kegigihan belajar siswa dan proses pembelajaran Kewirausahaan, siswa kelas IX TKR-1 di SMK Muh 2 Metro pada KD menunjukkan sikap pantang menyerah dan ulet dapat meningkat melalui pembelajaran menggunakan pembelajaran discovery inkuiri dan penugasan. Simpulan ini didasarkan pada temuan-temuan sebagai berikut:

1) Rata-rata hasil belajar pada prasiklus 4,38 meningkat menjadi 6,38 pada siklus I, kemudian meningkat menjadi 7,59 pada siklus II. Dengan demikian terdapat peningkatan hasil belajar dari prasiklus, siklus I, dan II. Peningkatan yang terjadi telah mencapai indikator yang direncanakan, yaitu 7,5. Kegigihan belajar Kewirausahaan juga mengalami peningkatan yang linier dari Prasiklus, Siklus I dan II. Dengan demikian siklus penelitian dihentikan karena telah mencapai indikator keberhasilan hasil belajar dan kegigihan belajar Kewirausahaan.

2) Pada siklus II, dari 32 siswa, 23 orang menjadi cukup gigih dan 27 memiliki kegigihan tinggi. Tidak ada siswa yang tidak dan kurang gigih. Peningkatan intensitas kegigihan siswa mencapai tingkat yang diinginkan. Presentase peningkatan semakin baik dan mencapai indikator keberhasilan yang direncanakan sebelumnya.

Berdasarkan hasilPTK dapat disarankan antara lain :

1) Berikan tujuan yang jelas pada saat penugasan. Hal dimaksudkan agar siswa tidak cepat putus asa karena tujuan yang akan dicapai tersebut dapat dijadikan dasar untuk menentukan cara meraihnya.

2) Berikan penugasan secara berkelompok dengan keluasan akses dan cara yang digunakan sehingga peran teman sebaya dapat dioptimalkan dalam menyelesaikan tugas yang diberikan.

3) Metode pembelajaran discovery inkuiri harus digunakan secara bertahap dengan melalui penugasan dan diskusi fase awal. Hal ini dilakukan untuk merubah kegigihan siswa;

4) Pada fase berikutnya, discovery inkuiri harus didorong dengan penugasan. untuk meningkatkan hasil belajar siswa;

5) Agar Kegigihan siswa selama pembelajaran tetap terjaga, maka penggunaan gambar harus mengarahkan pada kegiatan siswa secara teknis, terutama terkait dengan materi yang dibelajarkan. 
ISSN: 2442-4994 Vol.4. NNo.1 (2016) 74-83

\section{DAFTAR PUSTAKA}

Arikunto, Suharsimi; Suhardjono dan Supardi. 2006. Penelitian Tindakan Kelas. Jakarta: Bumi Aksara.

Gagne, M. Robert., Briggs J Leslie, Wager. W Walter. 1992. Principle of Instructional Design Fourth Edition. New York.

Ginanjar, Ary.2014. Bagaimana Mengembangkan Karakter Gigih. http://aryginanjar.com/bagaimanamengembangkan-karakter-gigih/

Gulo, 2008.Strategi BelajarMengajar Jakarta: PT. Gramedia Widiasaranaindonesia

Hamalik, O. 2007. Proses Belajar Mengajar. Jakarta: PT. Bumi Aksara.

Kasali, Rhenald.2010.Wirausaha Mandiri.Gramedia Pustaka Utama:Jakarta

Suprijono, A. 2011.Cooperative Learning.Yogyakarta : Pustaka Pelajar 
ISSN: 2442-4994 Vol.4. NNo.1 (2016) 74-83 